\title{
Functional trophic composition of the ichthyofauna of forest streams in eastern Brazilian Amazon
}

\author{
Gabriel Lourenço Brejão ${ }^{1}$, Pedro Gerhard ${ }^{2}$ and Jansen Zuanon ${ }^{3}$
}

\begin{abstract}
This study aimed to describe the functional organization of the ichthyofauna of forest streams from northeastern Pará State, Brazil, based on behavioral observation of species' feeding tactics. Seven streams were sampled between June and November, 2010, during snorkeling sessions, totaling $91 \mathrm{~h} 51 \mathrm{~min}$ of visual censuses at day, dusk, and night periods. Seventy three species distributed in six orders, 26 families and 63 genera were observed, with dominance of Characiformes, followed by Siluriformes. From information gathered by ad libitum observations, each species was included in one of 18 functional trophic groups (FTGs), according to two main characteristics: (1) its most frequently observed feeding tactic; and (2) its spatial distribution in the stream environment, considering their horizontal (margins or main channel) and vertical (water column) dimensions. The most frequent FTGs observed were Nocturnal invertebrate pickers ( 9 species), Diurnal channel drift feeders (8 spp.), Diurnal surface pickers ( $7 \mathrm{spp}$.), and Ambush and stalking predators (6 spp.). The FTGs herein defined enable a comparative analysis of the structure and composition of ichthyofauna in different basins and environmental conditions, which presents an alternative approach to the use of taxonomic structure in ecological studies. The ichthyofauna classification based in FTGs proposed in this study is compared to three other classifications, proposed by Sazima (1986), Sabino \& Zuanon (1998) and Casatti et al. (2001).
\end{abstract}

Este estudo teve como objetivo descrever a organização funcional da fauna de peixes de riachos do nordeste do estado do Pará, Brasil, com base em observações comportamentais das táticas alimentares das espécies. Sete igarapés foram amostrados entre junho e novembro de 2010 por técnicas de observações diretas durante sessões de mergulho livre, totalizando $91 \mathrm{~h} 51 \mathrm{~min}$ de observação, nos períodos diurno, crepuscular vespertino e noturno. Foram observadas 73 espécies distribuídas em seis ordens, 26 famílias e 63 gêneros, com predomínio de Characiformes, seguidos por Siluriformes. A partir de informações coligidas por observações ad libitum, as espécies foram organizadas em 18 grupos tróficos funcionais (GTFs), de acordo com duas características principais: (1) a tática alimentar observada com maior frequência; e (2) sua distribuição espacial no riacho, considerando suas dimensões lateral (margens e canal central) e vertical (coluna d'água). Os GTFs mais frequentes foram Catadores noturnos de invertebrados ( 9 espécies), Coletores diurnos de canal ( $8 \mathrm{spp}$.), Catadores diurnos de superfície (7 spp.), e Predadores de tocaia e emboscada (6 spp.). Os GTFs aqui definidos possibilitam uma análise comparativa da estrutura e composição da ictiofauna, que representa uma abordagem alternativa ao uso da estrutura taxonômica em estudos ecológicos. A classificação da ictiofauna baseada em GTFs proposta neste trabalho é comparada com outras três classificações, propostas por Sazima (1986), Sabino \& Zuanon (1998) e Casatti et al. (2001).

Key words: Feeding tactics, Natural history, Snorkeling.

\section{Introduction}

There are several factors that can contribute to determine the biological assemblages' structure and composition, including local environmental conditions and its temporal dynamics, and also intrinsic species features. However, there is no consensus about the relative importance of each of these factors on the assemblages' composition (Hérault, 2007).
Species with similar morphology, life history and autoecology can coexist in the aquatic environments (Frissell \& Lonzarich, 1996) and also depend on the resources availability to survive in those environments (Peres-Neto, 1999). A set of species that subsist on the same type of resources is defined as a guild (Root, 1967). According to Odum (1986), trophic guilds are formed by groups of species with comparable roles and niche dimensions inside an assemblage. Thus, guilds can be defined

\footnotetext{
${ }^{1}$ Universidade Federal do Pará - UFPA, Programa de Pós-Graduação em Ciências Ambientais, Campus Universitário do Guamá. Rua Augusto Corrêa 1, Instituto de Geociências, Câmpus Básico, 66075-110 Belém, PA, Brazil. gbrejao@gmail.com

${ }^{2}$ EMBRAPA Amazônia Oriental, Núcleo Temático em Gestão de Recursos Naturais. Travessa Dr. Enéas Pinheiro, s/nº, Caixa Postal 48, 66095-100 Belém, PA, Brazil.pgerhard@cpatu.embrapa.br

${ }^{3}$ Instituto Nacional de Pesquisas da Amazônia - INPA, Coordenação de Biodiversidade. Caixa Postal 2223, 69080-971 Manaus, AM, Brazil.jzuanon3@gmail.com
} 
independently of an organization based on taxonomic hierarchy, but from a common function that they play in the environment, allowing comparisons of the functional organization of different communities (Simberloff \& Dayan, 1991).

Trophic guilds are defined by the diet of the species and describe "what" the fish eat. Based on this information, and combining with the species morphology, it can be inferred "where" (e.g., water column, bottom) fish feeds (Matthews, 1998). The functional trophic group (FTG) concept advances by incorporating information about "how" the animal gets its food. Matthews (1998) emphasizes two important points: (1) knowing "how" fish feeds is related to the differences on the species ability to use similar food items; and (2) the way fish feeds can cause changes in the environment (e.g.: diggers may stir up benthic organic matter, debris and nutrients, or expose preys to other species while foraging), which could facilitate or inhibit foraging (and eventually the coexistence) of other species.

The way that fishes get their food is intimately related to their morphological and behavioral features. Food acquisition in fishes involves at least two main stages: (1) foraging (search, detection and approximation of the food item), and (2) feeding (capture and ingestion) (Keenleyside, 1979). The behavioral mechanisms used to obtain food by one species compose a feeding tactic (Alcock, 1993).

Although trophic ecology studies based on diet analysis allow the drawing of inferences about the feeding tactic(s) used by the species, direct observation of foraging behavior is usually the safest and most efficient way of obtaining this kind of information. The use of diving techniques for direct observation of the fishes is still rare as a sampling method in freshwater aquatic environments. However, this technique has been shown to be very efficient in behavioral studies, or to elucidate habitat use characteristics by the species (Uieda, 1984; Sazima, 1986; Sabino \& Castro, 1990; Buck \& Sazima, 1995; Sabino \& Zuanon, 1998; Casatti et al., 2001), generating information relevant to the natural history knowledge of freshwater fishes. This technique has the advantage of producing a low impact on the studied environment and, in addition, is considered to show low selectivity (Sabino \& Zuanon, 1998). This sampling efficiency is especially relevant in environments with high richness and diversity of fish species, like in the Amazon basin, where a small stream can contain dozens of species (e.g., Sabino \& Zuanon, 1998; Anjos \& Zuanon, 2007).

Nevertheless, the high diversity of species typical of most Amazon biological assemblages can make it hard to understand the ecological phenomena and faunal similarity patterns between study places and regions. Besides to the difficulties resulting from the selectivity of certain sampling methods, the occurrence of a significant percentage of rare species, represented by few individuals in a small fraction of the samples, can grossly underestimate the real ecological similarity between the compared assemblages. Furthermore, the use of ecological groups (replacing taxonomic groups) in comparative studies of biological assemblages can improve our ability to recognize and better understand general ecological patterns, facilitating comprehension of ecological processes that operate at local and regional scales.

As a contribution to the understanding of functional groupings of Amazon fishes, this study aims to define and characterize the functional trophic structure of the ichthyofauna of small forest streams at eastern Brazilian Amazon, based on direct underwater observation of habit use and feeding tactics of the species in their natural environment.

\section{Material and Methods}

\section{Study area}

The study was accomplished on the northeast region of Pará State, which is one of the oldest occupation areas of eastern Amazon, where smallholder properties predominate. As a consequence of this old occupation, the original vegetation was nearly completely removed, remaining a few fragments of secondary degraded forest, frequently along the riverine network (Watrin et al., 2009).

The main vegetation type in the past was Lowland Alluvial Dense Rain Forest, but nowadays it has been converted into cultivated fields and secondary vegetation of different ages (IBGE, 2004). The prevalent soil is Yellow Latosol, of medium texture and $\mathrm{pH}$ around 4.5, formed in Tertiary deposits of the Barreiras Group (Vieira et al., 2003). According to Köppen's system, local climate is Af(Tropical rainforest climate) (Pachêco \& Bastos, 2007). Total annual pluviosity varies around 2000 and $2800 \mathrm{~mm}$; however, the monthly rainfall amounts are not distributed homogeneously throughout the year: higher pluviosity occurs between March and April, and lower amounts of rain in September and October. The maximum annual average air temperature is $32.2^{\circ} \mathrm{C}$, with monthly averages ranging from $30.9^{\circ} \mathrm{C}$ (March) to $33.9^{\circ} \mathrm{C}$ (November) (Pachêco \& Bastos, 2007).

The streams that drain the region on flat terrain show sinuous unconfined channels with great structural complexity. The main channel overflows on the rainy season, flooding the forest zone adjacent for a few months. Substrate is predominantly sandy, with litter banks accumulating on the margins and depositional sections (pools); roots from riparian vegetation and submerged trunks and logs compose important habitat units, and are largely responsible for the channel structural complexity.

The studied stream reaches are located in the Maracanã and Marapanim River basins, at Igarapé-Açu, Marapanim and São Francisco do Pará counties (Fig. 1). Despite their proximity to the sea, they are not influenced by tide effects.

\section{Study sites selection}

The study was performed in small streams (orders 1 to 3 of Strahler's classification), in reaches with high structural integrity and in impoundments arising from anthropic changes. Favorable features to apply underwater observation techniques were considered, including local water horizontal transparency (at least $1 \mathrm{~m}$ ), average channel width (minimum $2 \mathrm{~m}$ ), and average depth $(1 \mathrm{~m})$. Stream reaches at places with evident signs of anthropogenic impacts (e.g., presence of human habitation in 


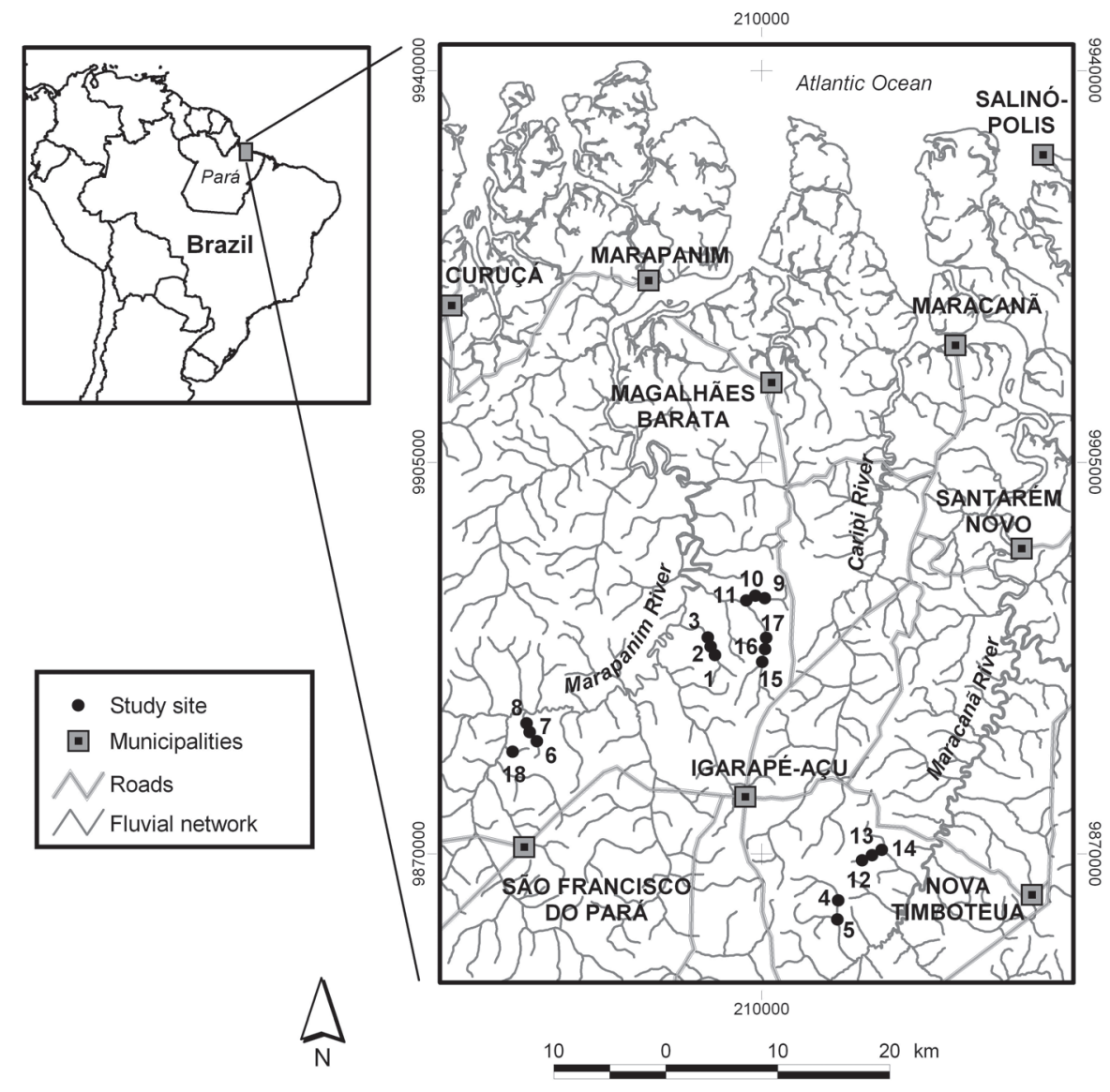

Fig. 1. Location of the 18 sampled streams reaches (enlarged detail) in the northeastern region of Pará. The road network shown on the map relates only to the main roads.

the surrounding areas, cattle presence or changes at riparian vegetation) were not included in this study.

Eighteen observation sites were installed in seven streams. Three of them are located on the Marapanim River basin (Marapanim county) and two in the Maracanã River basin (Igarapé-Açu county), all inserted in an area dominated by agricultural use. The remaining two streams also belong to the Marapanim river basin (São Francisco do Pará county), but are inserted in a forest matrix. Despite inserted in different environmental matrices, all studied streams were surrounded by riparian forest.

\section{Sampling}

Between June and November, 2010, 72 observations sessions were performed in seven streams, amounting $91 \mathrm{~h}$ $51 \mathrm{~min}$ of observations. The fishes were observed in $200 \mathrm{~m}$ long reaches of stream channel. In a previous study, it has been demonstrated that observations on a $200 \mathrm{~m}$ channel segment reveal between 98.1 and $100 \%(99.6 \% \pm 0.5, \mathrm{n}=54)$ of the estimated local richness.

Behavioral observations were conducted during snorkeling sessions, through ad libitum and focal animal (Lehner, 1999) methods. The observations in each sampled reach were performed in the downstream-upstream way, on three day periods, in order to observe the highest diversity of fish species in feeding activity: 1) diurnal (between 11:00 and 14:00); 2) dusk (between 17:00 and 18:30) and 3) nocturnal (between 19:00 and 21:00). During the nocturnal observations artificial illumination was used, provided by a diving headlamp. The observer moved upstream slowly $\left(\right.$ ca. $\left.7 \times 10^{-2} \mathrm{~m} . \mathrm{s}^{-1}\right)$ and collected information about the observed individuals. For each individual or group of individuals observed in activity, the day period, position in the channel (margin or main channel; vertical position on water column), environment (substrate type, presence of submerged trunks, macrophytes), and behavioral characteristics, were registered. The information about the species was written with pencil on polystyrene plates of $15 \times 20$ $\mathrm{cm}$ during the snorkeling sessions.

\section{Voucher specimens}

Specimens of observed fish species were collected, preserved in 10\% formalin, later washed in running water and maintained in $70 \%$ ethanol. The specimens were identified using identification keys (e.g., Géry, 1977; Planquette et al., 
1996, Keith et al., 2000 a, b; Galvis et al., 2006, SarmentoSoares \& Martins-Ribeiro, 2008) and deposited at a reference collection maintained by one of the authors (PG). A representative set of the collected material was deposited at the Ichthyological Collection of the Museu Paraense Emilio Goeldi (MPEG 21370 to MPEG 21454, Table 1).

\section{Functional Trophic Groups (FTGs)}

The FTGs were formed according to the most frequently observed feeding tactic for each species, combined with their spatial distribution (both vertical and horizontal) in the stream reach. It were considered "where", "how" and "when" different species feed, framed in 15 predefined feeding tactics: Surface pickers, Drift feeders, Roving predators, Stalking predators, Ambush predators, Mud-eaters, Diggers, Browsers, Grubbers, Nibblers, Sit-and-wait predators, Crepuscular to nocturnal predators ( $c f$. Sazima, 1986), Grazers, Parasites ( $c f$. Keenleyside, 1979), and Invertebrate pickers ( $c f$. Sabino \& Zuanon, 1998). The terms nektonic, nektobenthic and benthic follow the definitions of Lincoln et al. (1995): nektonic species are organisms that swim freely in the water column, nektobenthic species are organisms typically associated with the stream bottom that swim actively in the lower portion of the water column, and benthic species are organisms living on, in, or closed associated to the stream bottom.

\section{Results}

\section{Ichthyofauna characterization}

During sessions 73 species were observed, distributed in six orders, 26 families, and 63 genera, in the seven studied streams (Table 1). Characiformes (38.4\%) and Siluriformes $(31.5 \%)$ were the most representative orders in number of species. Characidae, with 15 species (20.5\%), and Cichlidae, with $10(13.7 \%)$, were the most representative families.

The ichthyofauna was composed predominantly of nektonic species which occupies the shallow areas close to the stream margins. Of the 73 species, 34 (46.6\%) are nektonic, $21(28.8 \%)$ nektobenthic and 18 (24.7\%) benthic (Table 1). Concerning to the lateral distribution, 44 species $(60.3 \%)$ have been associated to the margins, $19(26.0 \%)$ to the main channel and $10(13.7 \%)$ frequently move between these two compartments. Fifteen feeding tactics were used by the species observed at the studied streams, however, the most frequent feeding tactics were Drift feeders, performed by 23 species (31.5\%), and Surface pickers, by 21 species (28.8\%).

Characiformes species showed the highest amount of feeding tactics and functional trophic groups, followed by Siluriformes (Table 2). Among the families, Cichlidae showed the highest amount of feeding tactics $(n=5)$, followed by Characidae $(n=4)$.

\section{Functional Trophic Groups (FTGs).}

A list of the 18 FTGs identified among the fish species of the streams of northeastern Pará State is shown below, including a short description relating to FTGs proposed by other authors, the list of species composing each group, and a brief description of each observed feeding tactic.

Diurnal channel drift feeders . Nektonic species that collect food items drifting at mid-water and at the surface, predominantly in the main channel during the day ( $c f$. Sazima, 1986; Casatti et al., 2001).

Group composed by "lambaris" and "piabas" (tetras and characins, Characidae) that swim actively on the water column, suddenly investing on drifting particles or fallen in the water surface. Bryconops melanurus was observed at the main channel and in the pelagic zone of impounded stretches, swimming in schools of a least 20 individuals. Bryconamericus cf. diaphanus positions itself close to the stream bottom (5$10 \mathrm{~cm}$ above the substrate), between depressions of submersed sand dunes formed in high water current areas, collecting items stirred up by the water flow; they are usually observed alone and reacting aggressively to the approximation of conspecific. Iguanodectes rachovii and Moenkhausia collettii were observed very close to the margins with variable flow conditions, in groups of 3-30 individuals. Astyanax bimaculatus, Jupiaba anteroides, Moenkhausia cf. comma, and M. oligolepis were observed usually occupying the mid- lower strata of the water column close to the margins.

Diurnal backwater drift feeders. Nektonic species that occupy predominantly the backwaters, close to the margins and collect food items suspended in the water column or associated to the substrate (cf. Sazima, 1986; Casatti et al., 2001).

Group composed by small fish belonging to the Crenuchidae and to incertae sedis Characidae. Crenuchus spilurus remains stationary on the water column in slow flowing waters close to the margins, investing on items sinking nearby. Individuals of this species were observed occupying reentrances in the banks excavated by erosion processes. Hemigrammus cf. rodwayi and $H$. heterorhabdus form groups of 5-30 individuals and quickly invest in food particles carried by the current close to backwaters, in the upper (mid-water to surface) layers of the water column. Hemigrammus ocellifer was found mostly alone or in small groups of up to eight individuals, feeding on suspended particles in slow flowing water or speculating preys between branches and roots close to the margins. Groups ranging of 5- 10 individuals of Hyphessobrycon cf. bentosi were observed close to the bottom above litter banks, feeding on drifting particles and picking food deposited onto the substrate.

Diurnal surface pickers. Species occupying the uppermost layer of the water column close to the surface, predominantly at backwaters, were they pick food particles at surface or grasp small portions of periphyton during the day ( $c f$. Sabino \& Zuanon, 1998).

Group formed by the species of Lebiasinidae and of Cyprinodontiformes (Poeciliidae and Rivulidae). Most species were observed very close to marginal backwaters, sheltered among leaves, branches, macrophytes and roots of the banks, 
Table 1. List of fish species observed in the seven streams in northeastern Pará. The taxonomic categories are arranged according Buckup et al. (2007). * Proposed in this study.

\begin{tabular}{|c|c|c|c|c|c|}
\hline Order/Family/Species & Voucher (MPEG) & Vertical stratification & FTGs* & $\mathrm{N}$ & $\mathrm{FO}(\%)$ \\
\hline \multicolumn{6}{|l|}{ CHARACIFORMES } \\
\hline \multicolumn{6}{|l|}{ Curimatidae } \\
\hline Curimatopsis cf. crypticus Vari, 1982 & 21393 & Nektobenthic & Mud-eater & 3 & 42.9 \\
\hline \multicolumn{6}{|l|}{ Anostomidae } \\
\hline Leporinus cf. friderici (Bloch, 1974) & - & Nektonic & Nibbler & 2 & 28.6 \\
\hline \multicolumn{6}{|l|}{ Crenuchidae } \\
\hline Characidium fasciatum Reinhardt, 1867 & 21388 & Benthic & Sit-and-wait predator & 6 & 85.6 \\
\hline Crenuchus spilurus Günther, 1863 & 21390 & Nektonic & Diurnal backwater drift feeder & 4 & 57.1 \\
\hline \multicolumn{6}{|l|}{ Gasteropelecidae } \\
\hline Carnegiella strigata (Günther, 1864) & 21394 & Nektonic & Surface striker & 4 & 57.1 \\
\hline \multicolumn{6}{|l|}{ Characidae } \\
\hline Astyanax bimaculatus (Linnaeus, 1758) & 21371 & Nektonic & Diurnal channel drift feeder & 4 & 57.1 \\
\hline Bryconamericus $\mathrm{cf}$. diaphanus (Cope, 1878) & 21372 & Nektonic & Diurnal channel drift feeder & 2 & 28.6 \\
\hline Bryconops melanurus (Bloch, 1794) & 21374 & Nektonic & Diurnal channel drift feeder & 6 & 85.6 \\
\hline Charax cf. metae Eigenmann, 1922 & - & Nektonic & Ambush and stalking predator & 1 & 14.3 \\
\hline Gnathocharax steindachneri Fowler, 1913 & 21376 & Nektonic & Surface striker & 1 & 14.3 \\
\hline Hemigrammus cf. rodwayi Durbin, 1909 & 21399 & Nektonic & Diurnal backwater drift feeder & 3 & 42.9 \\
\hline Hemigrammus ocellifer (Steindachner, 1882) & 21396 & Nektonic & Diurnal backwater drift feeder & 5 & 71.4 \\
\hline Hyphessobrycon heterorhabdus (Ulrey, 1894) & 21377 & Nektonic & Diurnal backwater drift feeder & 7 & 100.0 \\
\hline Hyphessobrycon cf. bentosi Durbin, 1908 & 21379 & Nektonic & Diurnal backwater drift feeder & 4 & 57.1 \\
\hline Iguanodectes rachovii Regan, 1912 & 21381 & Nektonic & Diurnal channel drift feeder & 7 & 100.0 \\
\hline Jupiaba anteroides (Géry, 1965) & - & Nektonic & Diurnal channel drift feeder & 3 & 42.9 \\
\hline Metynnis cf. lippincottianus (Cope, 1870) & - & Nektonic & Browser & 2 & 28.6 \\
\hline Moenkhausia collettii (Steindachner, 1882) & 21384 & Nektonic & Diurnal channel drift feeder & 5 & 71.4 \\
\hline Moenkhausia cf. comma Eigenmann, 1908 & 21385 & Nektonic & Diurnal channel drift feeder & 7 & 100.0 \\
\hline Moenkhausia oligolepis (Günther, 1864) & - & Nektonic & Diurnal channel drift feeder & 1 & 14.3 \\
\hline \multicolumn{6}{|l|}{ Acestrorhynchidae } \\
\hline Acestrorhynchus cf. falcatus (Bloch, 1972) & - & Nektonic & Pursuit predator & 5 & 71.4 \\
\hline \multicolumn{6}{|l|}{ Erythrinidae } \\
\hline Hoplerythrinus unitaeniatus (Agassiz, 1829) & - & Nektobenthic & Ambush and stalking predator & 1 & 14.3 \\
\hline Hoplias cf. malabaricus (Bloch, 1794) & - & Nektobenthic & Ambush and stalking predator & 3 & 42.9 \\
\hline \multicolumn{6}{|l|}{ Lebiasinidae } \\
\hline Copella arnoldi (Regan, 1912) & 21400 & Nektonic & Diurnal surface picker & 1 & 14.3 \\
\hline Nannostomus beckfordi Günter, 1872 & 21403 & Nektonic & Diurnal surface picker & 2 & 28.6 \\
\hline Nannostomus eques Steindachner, 1876 & - & Nektonic & Diurnal surface picker & 1 & 14.3 \\
\hline Nannostomus trifasciatus Steindachner, 1876 & 21404 & Nektonic & Diurnal surface picker & 3 & 42.9 \\
\hline Pyrrhulina cf. laeta (Cope, 1872) & 21406 & Nektonic & Diurnal surface picker & 3 & 42.9 \\
\hline \multicolumn{6}{|l|}{ SILURIFORMES } \\
\hline \multicolumn{6}{|l|}{ Cetopsidae } \\
\hline Denticetopsis cf. ера Vari, Ferraris \& de Pinna, 2005 & 21437 & Nektonic & Crepuscular to nocturnal drift feeder & 5 & 71.4 \\
\hline Helogenes marmoratus Günther, 1863 & 21438 & Nektonic & Crepuscular to nocturnal drift feeder & 3 & 42.9 \\
\hline \multicolumn{6}{|l|}{ Aspredinidae } \\
\hline Bunocephalus coracoideus (Cope, 1874) & 21434 & Benthic & Crepuscular to nocturnal bottom predator & 1 & 14.3 \\
\hline \multicolumn{6}{|l|}{ Trichomycteridae } \\
\hline Paravandellia sp. & 21452 & Benthic & Parasites & 6 & 85.6 \\
\hline Trichomycterus hasemani (Eigenmann, 1914) & 21451 & Benthic & Crepuscular to nocturnal bottom predator & 2 & 28.6 \\
\hline \multicolumn{6}{|l|}{ Callichthyidae } \\
\hline Callichthys callichthys (Linnaeus, 1758) & - & Necktobenthic & Grubber & 1 & 14.3 \\
\hline Corydoras aff. acutus Cope, 1872 & - & Necktobenthic & Grubber & 2 & 28.6 \\
\hline Corydoras julii Steindachner, 1906 & - & Necktobenthic & Grubber & 1 & 14.3 \\
\hline Megalechis thoracata (Valenciennes, 1840) & - & Necktobenthic & Grubber & 1 & 14.3 \\
\hline \multicolumn{6}{|l|}{ Loricariidae } \\
\hline Ancistrus cf. hoplogenys (Günther, 1864) & 21443 & Benthic & Grazer & 4 & 57.1 \\
\hline Ancistrus sp. & - & Benthic & Grazer & 4 & 57.1 \\
\hline Farlowella cf. amazona (Günther, 1864) & - & Benthic & Grazer & 4 & 57.1 \\
\hline Hemiodontichthys acipenserinus (Kner, 1853) & 21444 & Benthic & Digger & 2 & 28.6 \\
\hline Rineloricaria cf. hasemani Isbrücker \& Nijssen, 1979 & - & Benthic & Grazer & 5 & 71.4 \\
\hline \multicolumn{6}{|l|}{ Pseudopimelodidae } \\
\hline Batrochoglanis cf. raninus (Valenciennes, 1840) & 21445 & Benthic & Crepuscular to nocturnal bottom predator & 1 & 14.3 \\
\hline
\end{tabular}

and in small reentrances in the banks in rather shallow areas $(1-3 \mathrm{~cm})$. When observed in stream impoundments, these species have always been associated with macrophytes stands and littoral areas, feeding at the surface or browsing periphyton-covered substrate. Nannostomus trifasciatus was observed always close to the surface and sheltered amid branches and roots of the riparian vegetation; differently of the rest of the group, it occupied the interface backwater/ main channel, occasionally investing on tiny food items slowly dragged by the current. 
Table 1. cont. List of fish species observed in the seven streams in northeastern Pará. The taxonomic categories are arranged according Buckup et al. (2007). * Proposed in this study.

\begin{tabular}{|c|c|c|c|c|c|}
\hline Order/Family/Species & Voucher (MPEG) & Vertical stratification & FTGs* & $\mathrm{N}$ & FO (\%) \\
\hline \multicolumn{6}{|l|}{ Heptapteridae } \\
\hline Mastiglanis asopos Bockmann, 1994 & 21440 & Benthic & Sit-and-wait predator & 3 & 42.9 \\
\hline Pimelodella sp. & - & Benthic & Crepuscular to nocturnal bottom predator & 5 & 71.4 \\
\hline Rhamdia mulleri (Günther, 1864) & 21441 & Benthic & Crepuscular to nocturnal bottom predator & 4 & 57.1 \\
\hline \multicolumn{6}{|l|}{ Doradidae } \\
\hline \multicolumn{5}{|l|}{ Auchenipteridae } & 14.3 \\
\hline Parauchenipterus galeatus (Linnaeus, 1758) & - & Nektonic & Crepuscular to nocturnal drift feeder & 3 & 42.9 \\
\hline Tatia gyrina (Eigenmann \& Allen, 1942) & 21435 & Nektonic & Crepuscular to nocturnal drift feeder & 3 & 42.9 \\
\hline Tatia intermedia (Steindachner, 1876) & - & Nektonic & Crepuscular to nocturnal drift feeder & 5 & 71.4 \\
\hline $\begin{array}{l}\text { Tetranematichthys barthemi Peixoto \& Wosiacki, } 2010 \\
\text { GYMNOTIFORMES }\end{array}$ & 21436 & Nektonic & Crepuscular to nocturnal drift feeder & 3 & 42.9 \\
\hline \multicolumn{6}{|l|}{ Gymnotidae } \\
\hline \multicolumn{5}{|l|}{ Sternopygidae } & 28.6 \\
\hline Eigenmannia cf. trilineata López \& Castello, 1966 & 21411 & Nektobenthic & Nocturnal invertebrate picker & 6 & 85.6 \\
\hline $\begin{array}{l}\text { Sternopygus macrurus (Bloch \& Steindachner, 1801) } \\
\text { Rhamphichthyidae }\end{array}$ & - & Nektobenthic & Nocturnal invertebrate picker & 2 & 28.6 \\
\hline $\begin{array}{l}\text { Gymnorhamphichthys petiti Géry \& Vu, } 1964 \\
\text { Hypopomidae }\end{array}$ & 21419 & Nektobenthic & Nocturnal invertebrate picker & 7 & 100.0 \\
\hline Brachyhypopomus beebei (Shultz, 1944) & 21412 & Nektobenthic & Nocturnal invertebrate picker & 1 & 14.3 \\
\hline Hypopygus lepturus Hoedeman, 1962 & 21415 & Nektobenthic & Nocturnal invertebrate picker & 2 & 28.6 \\
\hline Microsternarchus bilineatus Fernández-Yépez, 1978 & 21416 & Nektobenthic & Nocturnal invertebrate picker & 1 & 14.3 \\
\hline \multicolumn{6}{|l|}{ Apteronotidae } \\
\hline $\begin{array}{l}\text { Apteronotus cf. albifrons (Linneaus, 1766) } \\
\text { CYPRINODONTIFORMES }\end{array}$ & - & Nektobenthic & Nocturnal invertebrate picker & 1 & 14.3 \\
\hline \multicolumn{6}{|l|}{ Rivulidae } \\
\hline \multicolumn{5}{|l|}{ Poeciliidae } & 28.6 \\
\hline Micropoecilia parae (Eigenmann, 1894) & 21408 & Nektonic & Diurnal surface picker & 1 & 14.3 \\
\hline \multicolumn{6}{|l|}{ BELONIFORMES } \\
\hline Potamorrhaphis guianensis (Jardine, 1843) & 21370 & Nektonic & Pursuit predator & 5 & 71.4 \\
\hline \multicolumn{6}{|l|}{ PERCIFORMES } \\
\hline Aequidens cf. tetramerus (Heckel, 1840) & 21421 & Nektobenthic & Picker and browser & 4 & 57.1 \\
\hline Apistogramma caetei Kullander, 1980 & 21424 & Nektobenthic & Digger & 6 & 85.6 \\
\hline Cichla sp. & - & Nektonic & Ambush and stalking predator & 1 & 14.3 \\
\hline Crenicara punctulatum (Günther, 1863) & - & Nektobenthic & Digger & 4 & 57.1 \\
\hline Crenicichla saxatilis (Linnaeus, 1758) & 21429 & Nektobenthic & Ambush and stalking predator & 7 & 100.0 \\
\hline Crenicichla cf. johanna Heckel, 1840 & - & Nektobenthic & Ambush and stalking predator & 6 & 85.6 \\
\hline Heros cf. efasciatus Heckel, 1840 & 21430 & Nektobenthic & Picker and browser & 4 & 57.1 \\
\hline Krobia aff. guianensis (Regan, 1905) & - & Nektobenthic & Picker and browser & 2 & 28.6 \\
\hline Mesonauta sp. & - & Nektobenthic & Picker and browser & 1 & 14.3 \\
\hline Satanoperca jurupari (Heckel, 1840) & - & Nektobenthic & Digger & 4 & 57.1 \\
\hline
\end{tabular}

Surface strikers. Species that live close to the surface near to the margins, picking mainly invertebrates fallen from the riparian vegetation ( $c f$. Sazima, 1986).

Carnegiella strigata and Gnathocharax steindachneri were observed close to the margins, between branches and hanging roots from the riparian vegetation, quickly picking up particles fallen at the water surface by fast strikes propelled by their hypertrophied pectoral fins. Both species occasionally compose mixed schools, with G. steindachneri occupying a slightly lower position on the water column than C. strigata; in such situations, $C$. strigata was the most abundant species.

Ambush and stalking predators. Nektonic or nektobenthic species that capture preys by ambush and/or stalk ( $c f$.
Sazima, 1986; Sabino \& Zuanon, 1998).

Group composed by four families (Characidae, Erythrinidae, Gymnotidae, and Cichlidae) belonging to three orders (Characiformes, Gymnotiformes, and Perciformes). Charax cf. metae was observed stationary close to the margins during the day, near the bottom and ambushing its prey hidden among the vegetation or concealed by bank shadows. Hoplerythrinus unitaeniatus and Hoplias cf. malabaricus were observed hidden between branches and roots at the banks, ambushing their preys, especially at twilight and at night. Crenicichla saxatilis furtively approaches its prey (mostly aquatic invertebrates) concealed by the marginal vegetation, leaves or branches, from where it quickly attacks. Crenicichla $\mathrm{cf}$. 
Table 2. Number of feeding tactics, number of observed functional trophic groups (FTGs) and their respective proportions (\%) within each taxonomic order

\begin{tabular}{lccccc}
\hline \multirow{2}{*}{ Orders } & Species & \multicolumn{2}{c}{ Feeding tactics } & \multicolumn{2}{c}{ FTGs } \\
\cline { 3 - 6 } & & $\mathrm{n}$ & $\%$ & $\mathrm{n}$ & $\%$ \\
\hline Characiformes & 28 & 9 & 60.0 & 9 & 50.0 \\
Siluriformes & 23 & 7 & 46.7 & 7 & 38.9 \\
Perciformes & 10 & 5 & 33.3 & 3 & 16.7 \\
Gymnotiformes & 9 & 3 & 20.0 & 3 & 16.7 \\
Cyprinodontiformes & 2 & 2 & 13.3 & 1 & 5.6 \\
Beloniformes & 1 & 1 & 6.7 & 1 & 5.6 \\
\hline
\end{tabular}

johanna was also observed near the banks in shadowed areas, approximating furtively its prey. Only one individual of Cichla sp. was observed foraging under a bank shadow, apparently waiting to assault a prey. These three Cichlidae species forage during the day and at dusk. Gymnotus cf. coropinae was observed foraging at night always close to the margins, swimming slowly among the submersed roots and trunks, stalking preys.

Pursuit predators. Species that capture preys by pursuiting them close to the water surface ( $c f$. Goulding \& Carvalho, 1984; Sazima, 1986; Sabino \& Zuanon, 1998).

Acestrorhynchus cf. falcatus, a nektonic predator (Characiformes: Acestrorhynchidae), swims actively rovering in the stream looking for preys, both during the day and at twilight. When it localizes a potential prey, it makes a fast strike from the margin to the main channel. Potamorrhaphis guianensis, a surface Beloniformes, swims close to the margins amidst the marginal vegetation, where it attacks its preys (mostly invertebrates).

Mud-eaters. Nektobenthic species that scoop up and ingest substrate portions ( $c f$. Sazima, 1986).

Curimatopsis cf. crypticus (small sized Curimatidae) swims close to the stream bottom, repeatedly scooping portions from the substrate, usually fine particulate organic matter weakly settled on the substrate, leaving digging marks. It is observed alone or in groups of up to 10 individuals, foraging during the day or at twilight.

Nibblers. Nektonic species that bites and pick food items settled on solid substrates ( $c f$. Sazima, 1986).

Leporinus cf. friderici (a diurnal Anostomidae) occupies the lower half of the water column, searching for large food items (usually fruits) and biting them to cut small portions, which are facilitated by the incisiviform teeth; also forages picking invertebrates on the substrate.

Browsers. Nektonic species that bite off small pieces of macrophytes (cf. Sazima, 1986).

Metynnis cf. lippincottianus (diurnal and nektonic Serrasalmidae) prunes off macrophyte pieces or periphyton portions growing over trunks, branches and roots, plucking vegetal parts or epiphytic organisms that develop over these structures.

Sit-and-wait predators. Benthic species that capture preys by stalking (cf. Sazima, 1986; Zuanon et al., 2006).

Characidium fasciatus (Crenuchidae) and Mastiglanis asopos (Heptapteridae) hunt by stalking their prey. The former species keeps stationary, usually sheltered behind a trunk or rock and advances suddenly toward the closer preys; the fish moves at irregular intervals of time among foraging sites, making short displacements along the stream bottom. Mastiglanis asopos, always observed foraging at nighttime in sand bottom reaches, keeps stationary on the channel center with its long barbels and the filamentous dorsal and pectoral-fin rays distended, waiting food items swept by the current. When a prey or a particle touches its barbels or fin rays it invests quickly towards the prey.

Grazers. Benthic species that scratch algae attached to the substrate, mainly on trunks ( $c f$. Keenleyside, 1979).

Group formed exclusively by Loricariidae species, with predominantly nocturnal habits. Ancistrus hoplogenys and Ancistrus sp. have always been observed grazing on large trunks or rocky substrates, alone or in small groups. Farlowella cf. amazona was observed foraging in high current speed stream stretches, scratching algae attached to relatively thin branches ( 3 to $5 \mathrm{~cm}$ of diameter), in the long petioles of macrophytes (Nimpheaceae) and over gravel bottom. Rineloricaria cf. hasemani was also observed in high flow areas, scratching algae in thicker branches $(5-10 \mathrm{~cm}$ diameter) and trunks laid down in the stream bottom and in gravel banks as well.

Grubbers. Nektobenthic species that capture preys through substrate probing ( $c f$. Sazima, 1986).

Fishes of this group (representatives of the Callichthyidae) showed chiefly nocturnal habits and swim close to the stream bottom, moving the barbels through sediment particles of uppermost substrate layer; when a prey is localized, the fish quickly invests by immersing the snout into the substrate to grab it. Callichthys callichthys and Megalechis thoracata were observed close to the margins, searching the bottom mainly on patches of accumulated fine particulate organic matter. Corydoras aff. acutus and C. julii were observed probing the sandy substrate for preys, with little or none organic sediment deposits.

Diggers. Predominantly nektobenthic species that dig the substrate looking for food ( $c f$. Sazima, 1986).

Group formed by Hemiodontichthys acipenserinus (Loricariidae) and Apistogramma cf. caetei, Crenicara punctulatum and Satanoperca jurupari (Cichlidae) that forage digging the substrate with their mouths, selecting edible particles inside the oral cavity and eliminating the indigestible portion through their opercular openings. Such foraging mode leaves conspicuous marks (small depressions) on the substrate. Crenicara punctulatum and S. jurupari are diurnal fishes that 
swim alone or in small groups close to the bottom, plunging their protusible mouth and biting substrate portions (usually sand) near to the margins. Apistogramma cf. caetei, with diurnal habits, explores (solitary or in couples) predominantly the slow flowing stretches close to the margins, where it bites small portions of fine particulate organic matter, and shelters itself between branches and leaves deposited on the bottom. Hemiodontichthys acipenserinus shows a remarkable feeding tactic: foraging alone at night and supported: supported by its pectoral and pelvic fins, it projects its body forward and sinks the oral disk into the substrate (sand or organic debris); then, the fish resuspends and sucks the particles into the oral chamber (where the food is selected), expelling small clouds of sediments through the opercular openings.

Pickers and browsers. Predominantly nektobenthic species that grasps food portions adhered to the substrate and pick food items carried by the current over the substrate ( $c f$. Sabino \& Zuanon, 1998).

Group formed by Aequidens cf. tetramerus, Heros cf. efasciatus, Krobia aff. guianensis and Mesonauta sp. (Cichlidae), always observed close to the margins or in structurally complex channel places (usually with the presence of submerged trunks and roots) collecting food items dragged by the current close to the bottom. They also bite off portions of the periphyton cover.

Nocturnal invertebrate pickers. Fish of predominantly nektobenthic habits that capture preys close to the substrate during the night ( $c f$. Sabino \& Zuanon, 1998; Zuanon et al., 2006).

Group formed exclusively by the species of Gymnotiformes of several families, which search the channel substrate and banks looking for invertebrates and small fishes, using the electrolocation ability to detect prey. Apteronotus cf. albifrons and Sternopygus macrurus scroll through all the channel area looking for preys, which include fish (pers. obs.). Eigenmannia cf. trilineata and Steatogenys duidae search the substrate close the stream margins, but while the former occupies predominantly the mid-water to the bottom layer of the water column, the second occupies the whole water column. Brachyhypopomus beebei, Hypopygus lepturus and Microsternarchus bilineatus, capture invertebrates inside the litter banks by inserting their heads between the leaves. Gymnorhamphichthys petiti swims close to the stream bottom, repeatedly digging its long snout in the substrate while hovering head-down, keeping its body inclined regarding the substrate and moving forward.

Crepuscular to nocturnal drift feeders. Crepuscular-nocturnal species that capture drifting preys at the stream surface ( $c f$. Casatti et al., 2001).

Group formed by Cetopsidae and Auchenipteridae species that forage alone during the twilight and at night. Denticetopsis cf. epa and Tatia gyrina swim actively at the main channel and close to the surface, capturing food items that fall in the water and are drifted by the current. Helogenes marmoratus has a similar behavior, but explores predominantly the backwaters, capturing arthropods that fall in the water. Tatia intermedia also swim actively at the main channel, but collecting drifting food items at mid-water. Parauchenipterus galeatus and Tetranematichthys barthemi were observed always close to the margins, at mid-water, stationary or slowly swimming against the current, collecting food drifted by the current. All the species of this group, when observed, were alone.

Crepuscular to nocturnal bottom predators. Crepuscularnocturnal benthic species that search the substrate looking for small preys ( $c f$. Sazima, 1986).

Group of Siluriformes species that search for preys swimming close to the stream bottom. Trichomycterus hasemani swims fast and erratically over the bottom, searching for food and frequently burying itself into the substrate (usually sand patches). Pimelodella sp. swims at the main channel, in moderate current stretches, speculating the substrate with their barbels, looking for preys. Acanthodoras cataphractus, Batrochoglanis cf. raninus, and Rhamdia cf. quelen swim close to the margins searching for preys, mainly larger benthic macroinvertebrates and small fish, also exploring the environment with their barbels. Bunocephalus coracoideus swim close to the stream bottom on main channel, speculating the substrate with their small barbels.

Parasites. Parasite species that feed on blood of other fishes (cf. Keenleyside, 1979; Burgess, 1989).

Paravandellia sp.(small benthic Trichomycteridae) eats blood of larger fishes, attacking mainly their gills. When satisfied, it leaves the host and buries itself on the sand.

Although this feeding behavior was not observed, individuals of Paravandellia sp. were frequently seen in channels reaches where the main substrate was sand, actively swimming close to the bottom, mainly during the twilight. The individuals were seen moving around some dozens of centimeters during 15-30 seconds and then burying itself in the sand for some minutes. Some captured individuals showed clear signs of recently feeding, since the translucent ventral region evidenced a large portion of coagulated blood. The swimming habit resembles and may be confounded with that of T. hasemani.

The number of species in each FTG ranged from nine (12.0\% of the observed species in this study), for the Nocturnal invertebrate pickers, to one species each (1.4\%), for the mudeaters, nibblers, grazers and parasites.

Characidae showed the highest diversity FTGs' (5), followed by Cichlidae (3); 20 families (77\%) were represented by only one FTG. There was a positive correlation between species richness and the number FTGs represented in each family (Pearson's, $\mathrm{r}=0.88, \mathrm{p}<0.01, \mathrm{n}=26$ ) (Table 3 ).

A temporal partitioning in the use of space was observed in the studied streams. Thirty-nine species (53.3\%) showed diurnal habits, including all Characiformes 
Table 3. Number of feeding tactics, number of observed functional trophic groups (FTGs) and their respective proportions (\%) within each family.

\begin{tabular}{lccccc}
\hline \multirow{1}{*}{ Families } & Species & \multicolumn{2}{c}{ Feeding tactics } & FTGs \\
\cline { 2 - 6 } & & $n$ & $\%$ & $n$ & $\%$ \\
\hline Cichlidae & 10 & 5 & 33.3 & 3 & 16.7 \\
Characidae & 15 & 4 & 26.7 & 5 & 27.8 \\
Auchenipteridae & 4 & 2 & 13.3 & 1 & 5.6 \\
Cetopsidae & 2 & 2 & 13.3 & 1 & 5.6 \\
Crenuchidae & 2 & 2 & 13.3 & 2 & 11.1 \\
Heptapteridae & 3 & 2 & 13.3 & 2 & 11.1 \\
Lebiasinidae & 5 & 2 & 13.3 & 1 & 5.6 \\
Loricariidae & 5 & 2 & 13.3 & 2 & 11.1 \\
Poeciliidae & 1 & 2 & 13.3 & 1 & 5.6 \\
Rivulidae & 1 & 2 & 13.3 & 1 & 5.6 \\
Trichomycteridae & 2 & 2 & 13.3 & 2 & 11.1 \\
Acestrorhynchidae & 1 & 1 & 6.7 & 1 & 5.6 \\
Anostomidae & 1 & 1 & 6.7 & 1 & 5.6 \\
Apteronotidae & 1 & 1 & 6.7 & 1 & 5.6 \\
Aspredinidae & 1 & 1 & 6.7 & 1 & 5.6 \\
Belonidae & 1 & 1 & 6.7 & 1 & 5.6 \\
Callichthyidae & 4 & 1 & 6.7 & 1 & 5.6 \\
Curimatidae & 1 & 1 & 6.7 & 1 & 5.6 \\
Doradidae & 1 & 1 & 6.7 & 1 & 5.6 \\
Erythrinidae & 2 & 1 & 6.7 & 1 & 5.6 \\
Gasteropelecidae & 1 & 1 & 6.7 & 1 & 5.6 \\
Gymnotidae & 1 & 1 & 6.7 & 1 & 5.6 \\
Hypopomidae & 4 & 1 & 6.7 & 1 & 5.6 \\
Pseudopimelodidae & 1 & 1 & 6.7 & 1 & 5.6 \\
Rhamphichthyidae & 1 & 1 & 6.7 & 1 & 5.6 \\
Sternopygidae & 2 & 1 & 6.7 & 1 & 5.6 \\
\hline & & & & & \\
\hline & & & &
\end{tabular}

(except Erythrinidae), Beloniformes, Cyprindontiformes, and Perciformes. These species were almost replaced at night by Erythrinidae, and representatives of several families of Siluriformes and Gymnotiformes, totaling 34 species (46.6\%). Nevertheless, such taxonomical changeover was not corresponded by a similar functional modification. Three (16.7\%) of the FTGs observed during the day (Diurnal channel drift feeders, Diurnal backwater drift feeders, Diurnal surface pickers) were replaced by similar functional groups at night (Crepuscular to nocturnal drift feeders); FTGs recorded exclusively in one time period were Diurnal channel drift feeders, Diurnal backwater drift feeders, Diurnal surface pickers, Surface strikers, Nibblers, Browsers and Pickers during the day, and Crepuscular to nocturnal drift feeders, Crepuscular to nocturnal predators, Nocturnal invertebrate pickers and Parasites at night.

\section{Discussion}

\section{Stream habitat heterogeneity}

It was observed on the studied streams that the margins shows higher structural complexity provided by specific habitat subunits (e.g., undercut banks, Frissell et al., 1986), roots from the riparian forest, higher amount of submerged trunks and branches, macrophytes patches and recesses caused by erosion on the margins close to the surface. Most of the streams drain relatively narrow $\left(\sim 10^{2} \mathrm{~m}\right)$ flat-bottomed valleys and show a complex morphology, with substrate composed mostly by vegetal matter (litter, branches, trunks) from the riparian forest (in the studied areas frequently with Igapó components) and alluvial sediments (sand, silt, clay). These unconstrained streams show many secondary channels that may connect to small flooded areas; a seasonal and dynamic environment that expands and recedes following slight variations on the stream water level. This lateral complexity is largely exploited by the fishes observed in this study. The central (main) channel portion provides less shelter for smaller fishes, regarding to ambush points by bigger fishes; moreover, when using the central channel area, fishes may become vulnerable to aquatic predators attack (Power, 1984). The spatial distribution of the species indicates the occurrence lateral and vertical stratification of the stream fish assemblage, as well as the body shape may provide information about microhabitat use.

The margins were the mostly used compartment by the fish species found in this study, agreeing with the lateral distribution pattern described by Sabino \& Zuanon (1998) in a Central Amazon stream, where $72.4 \%$ of the observed species occupied this local. Uieda (1984), Costa (1987), Sabino \& Castro (1990) and Sabino \& Silva (2004) also detected this pattern in streams of southeastern Brazil, which indicate that this form of horizontal stratification represents a common feature of Brazilian tropical stream fish assemblages.

Concerning to the vertical stratification, there was a predominance of nektonic species, counter to the pattern found by Sabino \& Zuanon (1998), where $65.5 \%$ of the sampled species showed benthic habits. This difference might have occurred because these authors considered as benthic all species that have feeding activity on the bottom of the stream, including the nektobenthics.

Habitat heterogeneity is known to have strong effects on fish species distribution along streams, both in relation to longitudinal distribution and diversity of microhabitats (Angermeier \& Karr, 1983; Sabino \& Castro, 1990). The sampling of relatively long streams reaches, ranging from 200 to $280 \mathrm{~m}$, increases the possibility of including a great variety of microhabitats, reducing the possible bias of underrepresenting the distribution patterns of rare species or habitat-specialists (Angermeier \& Smogor, 1995; Anjos \& Zuanon, 2007). In fact, the $200 \mathrm{~m}$ long reaches were adequate to sample efficiently the ichthyofauna of the selected streams and impoundments for this study by means of underwater observation, including up to $95 \%$ of the estimated local species richness.

\section{FTGs, fish morphology and behavior}

The number and variety of feeding tactics used by the species of each family (Table 3) possibly reflect the morphological diversity of the Characidae and Cichlidae. When the taxonomic level is raised to order, the FTGs show the same pattern found for the ichthyofauna composition, with Characiformes showing the greatest FTGs amount of types, followed by Siluriformes, Gymnotiformes and Perciformes. When comparing the feeding behavior similarities of marine and freshwater fish assemblages, Sazima (1986) reports that Characidae and Cichlidae showed half 
of the feeding tactics exhibited by six marine fish families, suggesting that the morphological diversity of these two families is responsible for the variety of tactics and range of environments explored by them.

In this study, the group composed by the nektonic Characidae species that collect food items drifted by the current at the surface was divided in two subunits: (1) channel drift feeders and surface pickers and, (2) margin drift feeders and surface pickers. This is justified mainly by the fact that these species show differences in their horizontal distribution, which can be related to fish body size. Species belonging to the margin subunit are small, and the structurally more complex margins may provide protection against possible predators. The higher the habitat complexity, the smaller are the chances of a predator to severely impact a prey population (Power $e t$ al., 1985). On the other hand, channel subunit includes medium-sized species, mostly of agile swimmers, that possibly can evade from the predators attack, allowing them to occupy the central (and more exposed) region of the stream.

Five sand-dwelling species were observed, Bryconamericus cf. diaphanus (Characidae), Gymnorhamphichthys petiti (Rhamphichthyidae), Mastiglanis asopos (Heptapteridae), Paravandellia sp. and Trichomycterus hasemani (Trichomycteridae), which shows translucent body or cryptic coloration pattern on the sand (Zuanon et al., 2006). Except for $B$. cf. diaphanus, the other four species showed crepuscularnocturnal activities and bury themselves in the sand during the day.

As a Loricariidae, Hemiodontichthys acipenserinus was expected to be a grazer, since the species of this family have the morphological features that allow them to use the abundant periphyton cover available in streams. However, $H$. acipenserinus is a digger that excavates the substrate, to feed on particulate organic matter and small organisms associated to it, similarly to species of Cichlidae, sustaining the inclusion of this species on this functional category.

\section{Temporal organization of the fish assemblages}

The studied ichthyofauna was composed by two main groups of species that alternate the use of the space and food resources. The micro-habitats where similarly explored by diurnal and nocturnal species that employ the same (or very similar) feeding tactics (e.g., Surface pickers, Drift feeders Stalking predators, Ambush predators, Diggers, and Sit-andwait predators), despite the phylogenetic and morphological differences between them.

Although not directly investigated in this study, it is probable that there are differences in the food items eaten by the Diurnal channel drift feeders (Characidae), Diurnal backwater drift feeders (Characidae and Crenuchidae), Surface strikers (Characidae and Gasteropelecidae) and Crepuscular to nocturnal drift feeders (Auchenipteridae and Cetopsidae). The species that compose all these FTGs are predominantly insectivorous, but the diurnal species mainly eat terrestrial insects, while the nocturnal species consume mostly aquatic insects (Sabino \& Zuanon, 1998). The shade produced by the riparian forest is a limiting factor to the primary productivity of aquatic systems, and fish are strongly dependent of allochthonous resources that fall in the stream during the day (Lowe-McConnell, 1999). Intentional drifting of living aquatic insects occurs mainly during the night, probably as a behavioral defense against predation by diurnal fish, which are much more abundant than nocturnal species (Flecker, 1992). In fact, the diversity of FTGs and species that feed on drifting invertebrates is considerably higher during the day (three FTGs) than in the night (just one), which is probably related to a higher effectiveness of feeding tactics that rely on visual detection of the prey.

At night, Nocturnal invertebrate pickers (Gymnotiformes), Crepuscular to nocturnal bottom predators (Siluriformes) and Grubbers (Siluriformes) use the same micro-habitats used by the Pickers and browsers (Cichlidae) and Diggers (Cichlidae) during the day, actively looking for small invertebrates and fish at the stream bed. The detection and capture of prey by species of Gymnotiformes and Siluriformes are possible by the use of electrically and chemically oriented senses, and do not depend on the presence of light. This situation seems to represent a counterpart to the predominance of the consumption of drifting invertebrates at the upper layers of the water column by visually oriented species of Characiformes during the day.

\section{FTGs as a tool for fish assemblage comparisons}

Grouping the species into functional trophic groups allows the comparison of fish assemblage structure from different environments, river basins, and even biogeographic origins. Different species that show similar morphological features tend to perform the same ecological functions and to occupy the same microhabitats, whether in tropical or temperate communities, in freshwater or marine environments (Sazima, 1986; Winemiller, 1991). Observed functional patterns may be used to infer on the nature of ecological processes, respecting the characteristics of abundance, distribution and species diversity (Cassemiro \& Padial, 2008). In this study, the observed species were organized in 18 FTGs, which can be compared to the results of similar works performed in a freshwater pond and in a marine environment (Sazima, 1986); in a Central Amazon stream (Sabino \& Zuanon, 1998); and in streams from the upper Paraná River basin (Casatti et al., 2001). In those studies, fish species were organized according to their functional similarity, allowing to the authors to identify more than one feeding tactic being used by a species group. A comparison of the FTGs defined in the present study, with the three works above cited is depicted in Fig. 2.

Functional traits can be used to assess the convergence between communities that, due to different evolutionary histories, otherwise could not be compared. A strong functional convergence of communities in different continents could be observed regarding to the use of similar microhabitats, to the relations between assemblage patterns 


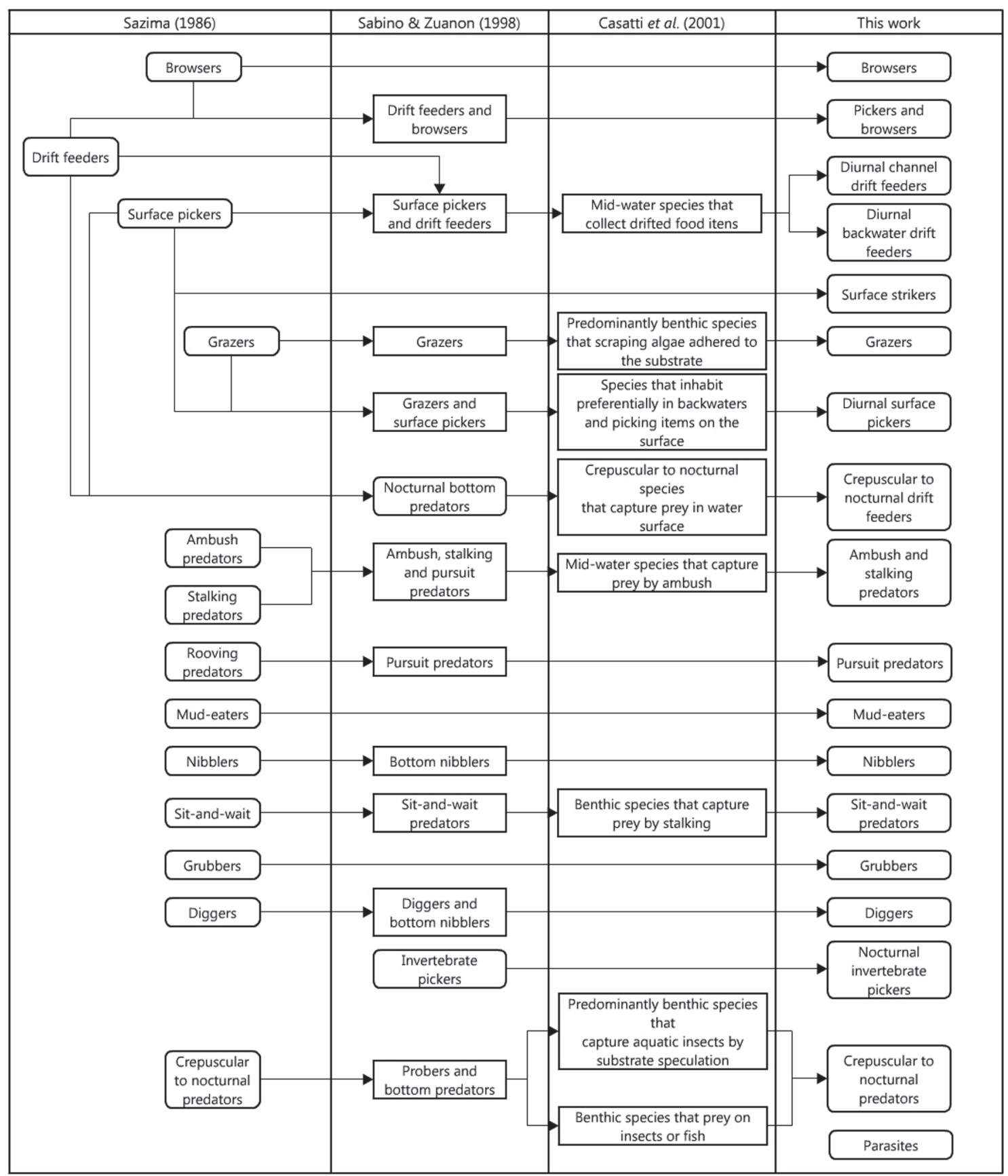

Fig. 2. Comparison between the classification of functional trophic groups proposed by this study and three other similar studies.

and environmental features, or to the longitudinal distribution of functional groups in the drainage network (Lamouroux et al., 2002).

An assemblage organization in functional trophic groups is proposed in order to allow comparison among different hydrographic systems, minimizing the taxonomic particularities of their ichthyofauna (biogeographic effects). The analysis of an assemblage according to its taxonomic organization reveals the distribution patterns of the species, but when analyzed through a functional approach, the same assemblage can be divided according to the habitat template (Southwood, 1977; Poff \& Ward, 1990). Large scale processes determine the potential pool of species to occur in a specific locality, strongly influencing the local assemblage structure. However, the functional responses of an assemblage to the environmental variables occur independently of the species taxonomic history (Hoeinghaus et al., 2007). This approach allows us to infer about the differences or similarities 
between biological communities in distinct environments, hopefully speeding up our understanding of the ecological processes that enables the coexistence of so many species in a rapidly changing world.

\section{Acknowledgments}

The authors wish to acknowledge Embrapa Amazônia Oriental for providing logistics for the fieldwork, $\mathrm{CNPq}$ (Process number 574.648/2008-9) for financial support, and FAPESPA for GB study fellowship (020/2008 Edital). JZ receives a productivity grant from CNPq (process number 307464/2009-1). Fish collection was possible due to the permit 22111-1 issued by ICMBio. Wolmar Wosiacki, curator of fishes on the Museu Paraense Emílio Goeldi, kindly received specimens collected during our field campaigns. The authors are thanks to Anderson Ferreira for his valuable help at fieldwork and for insightful discussions on fish feeding behavior. This is contribution \# 30 of Projeto Igarapés.

\section{Literature Cited}

Alcock, J. 1993. Animal Behaviour. Sinauer Associates, Sunderland.

Angermeier, P. L. \& J. R. Karr. 1983. Fish communities along environmental gradients in a system of tropical streams. Environmental Biology of Fishes, 9: 117-135.

Angermeier, P. L. \& R. A. Smogor. 1995. Estimating number of species and relative abundances in stream-fish communities: effects of sampling effort and discontinuous spatial distributions. Canadian Journal of Fisheries and Aquatic Sciences, 52: 936-949.

Anjos, M. B. \& J. Zuanon. 2007. Sampling effort and fish species richness in small terra firme forest streams of central Amazonia, Brazil. Neotropical Ichthyology, 5: 45-52.

Buck, S. \& I. Sazima. 1995. An assemblage of mailed catfishes (Loricariidae) in southeastern Brazil: distribution, activity, and feeding. Ichthyological Exploration of Freshwaters, 6: 325-332.

Buckup, P. A., N. A. Menezes \& M. S. Ghazzi. 2007. Catálogo das espécies de peixes de água doce do Brasil. Museu Nacional, Rio de Janeiro.

Burgess, W. E. 1989. An atlas of freshwater and marine catfishes: a preliminary survey of the Siluriformes. Neptune, TFH Publications.

Casatti, L., F. Langeani \& R. M. C. Castro. 2001. Peixes de riacho do Parque Estadual do Morro do Diabo, Bacia do Alto Rio Paraná, SP. Biota Neotropica, 1: 1-15.

Cassemiro, F. A. S. \& A. S. Padial. 2008. Teoria Neutra da Biodiversidade e Biogeografia: Aspectos Teóricos, Impactos na Literatura e Perspectivas. Oecologia Brasiliensis, 12: 706-719.

Costa, J. E. M. 1987. Feeding habits of a fish community in a tropical coastal stream, Rio Mato Grosso, Brazil. Studies on Neotropical Fauna and Environment, 22: 145-153.

Flecker, A. S. 1992. Fish predation and the evolution of invertebrate drift periodicity: evidence from neotropical streams. Ecology, 73: 438-448.

Frissell, C. A., W. J. Liss, C. E. Warren \& M. D. Hurley. 1986. A hierarchical framework for stream habitat classification: viewing streams in a watershed context. Environmental Management. 10: $199-214$

Frissell, C. A. \& D. G. Lonzarich. 1996. Habitat use and competition among stream fishes. Pp. 493-510. In: Hauer, F. R. \& G. A. Lamberti. (Eds.). Methods in Stream Ecology. San Diego, Academic Press.
Géry, J. 1977. Characoids of the world. Neptune City, TFH Publications.

Goulding, M. \& M. L. Carvalho. 1984. Ecology of Amazonian Needlefishes (Belonidae). Revista Brasileira de Zoologia, 2: 99 111.

Hérault, B. 2007. Reconciling niche and neutrality through the emergent group approach. Perspectives in Plant Ecology, Evolution and Systematics. 9: 71-78.

Hoeinghaus, D. J., K. O. Winemiller \& J. S. Birnbaum. 2007. Local and regional determinants of stream fish assemblage structure: inferences based on taxonomic vs. functional groups. Journal of Biogeography. 34: 324-338.

Instituto Brasileiro de Geografia e Estatística (IBGE). Mapa de vegetação do Brasil. 2004. Available from: http:// geoftp.ibge.gov.br/mapas/tematicos/mapas_murais/ vegetacao.pdf/ (Date of access: 03/2011).

Keenleyside, M. H. A. 1979. Diversity and Adaptations in Fish Behaviour. Berlin, Springer-Verlag.

Keith, P., P.-Y. Le Bail \& P. Planquette. 2000a. Atlas des poissons d'eau douce de Guyane. Tome 2, fascicule I: Batrachoidiformes, Mugiliformes, Beloniformes, Cyprinodondiformes, Synbranchiformes, Percifomes, Pleuronectiformes, Tetraodontiformes. Paris, Publications scientifiques du M.N.H.N.

Keith, P., P.-Y. Le Bail \& P. Planquette. 2000b. Atlas des poissons d'eau douce de Guyane. Tome 2, fascicule II: Siluriformes. Paris, Publications scientifiques du M.N.H.N.

Lamouroux, N., N. L. Poff \& P. L. Angermeier. 2002. Intercontinental convergence of stream fish community traits along geomorphic and hydraulic gradients. Ecology, 83: 1972-1807.

Lehner, P. N. 1996. Handbook of ethological methods. $2^{\text {nd }}$ ed. Cambridge, Cambridge University Press.

Lincoln, R. J., G. A. Boxshall \& P. F. Clark. 1995. Diccionario de ecología, evolución y taxonomía. Mexico, Fondo de Cultura Económica.

Lowe-McConnell, R. H. 1999. Estudos Ecológicos de Comunidades de Peixes Tropicais. São Paulo, EDUSP.

Matthews, W. J. 1998. Patterns in freshwater fish ecology. Norwell, Chapman \& Hall.

Odum, E. P. 1986. Ecologia. Rio de Janeiro, Guanabara Koogan.

Pachêco, N. A. \& T. X. Bastos. 2007. Boletim agrometeorológico 2006 Igarapé-Açu. Belém, Embrapa Amazônia Oriental.

Parrish, J. 1995. Fish Behaviour. Pp. 42-47. In: Paxton, J. R. \& W. N. Eschmeyer (Eds.). Encyclopedia of fishes: a comprehensive guide by international experts. Academic Press, San Diego.

Peres-Neto, P. R. 1999. Alguns métodos e estudos em ecomorfologia de peixes de riachos. Pp. 209-236. In: Caramaschi, E. P., R. Mazzoni, R. \& P. R. Peres-Neto (Eds.). Ecologia de Peixes de Riachos. Série Oecologia Brasiliensis.

Planquette, P., P. Keith \& P.-Y. Le Bail. 1996. Atlas des poissons d'eau douce de Guyane. Tome I. Paris, Publications scientifiques du M.N.H.N. 22.

Power, M. E. 1984. Depth distributions of armored catfish predator-induced resource avoidance? Ecology. 65: 523-528.

Root, R. B. 1967. The niche exploitation pattern of the blue-gray gnat-catcher. Ecological Monographs, 37: 317-350.

Sabino, J. \& R. M. C. Castro. 1990. Alimentação, período de atividade e distribuição espacial dos peixes de um riacho da Floresta Atlântica (sudeste do Brasil). Revista Brasileira de Biologia, 50: 23-26.

Sabino, J. \& C. P. D. Silva. 2004. História natural de peixes da estação ecológica Juréia-Itatins. Pp. 230-242. In: Marques, O. 
A. V. \& W. Duleba. (Eds.). Estação ecológica Juréia-Itatins: ambiente físico, flora e fauna. Ribeirão Preto, Holos.

Sabino, J. \& J. Zuanon. 1998. A stream fish assemblage in Central Amazonia: distribution, activity patterns and feeding behavior. Ichthyological Exploration of Freshwaters, 8: 201-210.

Sarmento-Soares, L. M. \& R. F. Martins-Ribeiro. 2008 A systematic revision of Tatia (Siluriformes: Auchenipteridae: Centromochlinae). Neotropical Ichthyology, 6: 494-542.

Sazima, I. 1986. Similarities in feeding behavior between some marine and freshwater fishes in two tropical communities. Journal of Fish Biology, 29: 53-65.

Simberloff, D. \& T. Dayan. 1991. The guild concept and the structure of ecological communities. Annual Reviews of Ecology and Systematics, 22: 115-143.

Sutherland, W. J. 1996. Ecological Census Techniques: A Handbook. Cambridge University Press, Cambridge.

Uieda, V. S. 1984. Ocorrência e distribuição dos peixes em um riacho de água doce. Revista Brasileira de Biologia, 44: 203-213.

Vieira, I. C., A. S. Almeida, E. A. Davidson, T. A. Stone, C. R. Carvalho \& B. Guerrero. 2003. Classifying successional forests using Landsat spectral properties and ecological characteristics in eastern Amazônia. Remote Sensing of Environment, 87: 470481.

Watrin, O. S., P. Gerhard \& M. N. M. Maciel. 2009. Dinâmica do uso da terra e configuração da paisagem em antigas áreas de colonização de base econômica familiar, no nordeste do estado do Pará. Geografia, 34: 455-479.

Winemiller, K. O. 1991. Ecomorphlogical diversification in lowland freshwater fish assemblages from five biotic regions. Ecological Monographs, 61: 343-365.

Zuanon, J., F. A. Bockmann \& I. Sazima. 2006. A remarkable sanddwelling fish assemblage from central Amazonia, with comments on the evolution of psammophily in South American freshwater fishes. Neotropical Ichthyology, 4: 107-118.

Submitted September 13, 2012 Accepted April 8, 2013 by Norma S. Hahn Published June 28, 2013 